\title{
Involvement of Plasmid DNA in the Productivity of Coronatine by Pseudomonas syringae pv. atropurpurea
}

\author{
Mamoru SAto*, Koushi Nishiy ama** and Akira Shirata** \\ 佐藤 守*・西山幸司**・白田 昭**: Pseudomonas syringae pv. atropurpurea \\ のコロナチン生産性とプラスミドDNA との関係
}

\begin{abstract}
Pseudomonas syringae pv. atropurpurea, a causal agent of halo blight of Italian ryegrass, produces coronatine (Cor) which is a toxin inducing halo blight lesions on the leaves. The relationship between Cor productivity and a specified plasmid DNA in this bactreium was studied. The plasmid of approximately 58 Mdal named as pCORl was detected in all of the $34 \mathrm{Cor}^{+}$wild strains tested including NIAS 1309. On the contrary, none of pCORl was detected in all of the Cor- strains obtained as spontaneous mutants from NIAS 1309 or isolated from the host plants. Furthermore, all of the $38 \mathrm{Cor}^{-}$mutants obtained from NIAS 1309 by the treatment with acridine orange (75 to $200 \mathrm{ppm}$ ) simultaneously lost pCORl plasmid completely. Among them, however, 29 mutants still harboured a smaller plasmid (about $40 \mathrm{Mdal}$ ) seemed to be a defective pCORl. These results strongly suggest that the plasmid pCOR1 codes Cor productivity of the bacterium.
\end{abstract}

(Received March 12, 1983)

Key Words : Pseudomonas syringae pv. atropurpurea, coronatine, plasmid.

\section{Introduction}

Pseudomonas syringae pv. atropurpurea (Reddy and Godkin 1923) Young, Dye and Wilkie 1978 (abbrev. pv. atropurpurea) is a causal agent of halo blight of Italian ryegrass (Loium multiflorum Lam. $)^{18)}$. The bacterium produces a physiologically active substance named as coronatine, known to be indispensable for developing symptoms of halo blight ${ }^{7,10,11,14)}$. Coronatine (Cor) productivity of the bacterium is detectable by activity of inducing hypertrophic growth of potato tuber tissues after inoculation of the pathogen ${ }^{10,11)}$. Junior author obtained some avirulent mutants from a virulent strain of pv. atropurpurea during its subculturing. Many avirulent strains were also isolated from diseased plants. He found that the bacteriological properties of these avirulent strains were much the same as those of the virulent strains of pv. atropurpurea except virulence ${ }^{12)}$. The phenomena mentioned above suggest that the gene( $s$ ) involved to Cor productivity might be encoded on the indigenous plasmid of the bacterium.

A definite evidence of plasmid-coded determinants of pathogenicity in plant pathogenic bacteria has been shown in Agrobacterium tumefaciens ${ }^{19,20)}$ and Pseudomonas

\footnotetext{
* Sericultural Experiment Station, Yatabe, Ibaraki 305, Japan 蛋糸試験場

** National Institute of Agricultural Sciences, Yatabe, Ibaraki 305, Japan 農業技術研究所
} 
syringae pv. savastano $i^{2,3)}$. The existance of plasmid controling pathogenicity has been suggested with Pseudomonas syringae pv. syringae ${ }^{5)}$ and some other bacteria. Since the coronatine productivity is indispensable for pathogenicity of pv. atropurpurea, we attempted to make clear whether the coronatine productivity of this bacterium is encoded on some plamid or not.

\section{Materials and Methods}

Bacterial strains and plasmids. The main strains of pv. atropurpurea used in this experiment and their phenotype are shown in Table 1. All of the Cor ${ }^{+}$strains of pv. atropurpurea are pathogenic, while $\mathrm{Cor}^{-}$strains are non-pathogenic. Besides these strains, 32 of the virulent and 37 of the avirulent strains isolated from the diseased ryegrass leaves were also used (Table 3 ).

Some plasmids, such as RSF 1010 (5.5 Mdal), pBPWl (30 Mdal), pBPWl :: Tn 7 (39 Mdal) and pAS8T $c^{\mathrm{s}} \mathrm{repl}::$ Tn 7 (52 Mdal) were used as markers for standard molecular weight. They were kindly supplied by Dr. N. J. Panopoulos ${ }^{15,17)}$.

Detection of plasmids. Bacteria were grown overnight in liquid King's B (KB) medium $^{8)}$ at $28 \mathrm{C}$ and plasmid DNA was extracted according to the mothod described by Birnboim and Doly ${ }^{1}$. Plasmd DNA was analysed by electrophoresis at $18 \mathrm{~mA}$ and 100 volts in $0.7 \%$ agarose (Sigma, Type 1, Low EEO) gel with Tris-borate buffer ( $89 \mathrm{mM}$ Tris base, $2.5 \mathrm{mM}$ disodium EDTA and $8.9 \mathrm{mM}$ boric acid). The gels were stained with ethidium bromide $(1 \mu \mathrm{g} / \mathrm{ml})$ and photographed under UV illumination after the electrophoresis. The molecular size of the plasmid was' estimated in comparison with that of the standard plasmid DNA in the same gel.

Curing method. Curing test was performed by a modification of the technique described by Comai and Kosuge ${ }^{2)}$. Tubes containing $5 \mathrm{ml}$ of $\mathrm{KB}$ broth supplemented with a specified concentration of acridine orange were inoculated with bacterial cells of $\log$-phase to give a final concentration of $10^{6-7} / \mathrm{ml}$. After the cultures were shaken at $28 \mathrm{C}$ for $48 \mathrm{hr}, 0.1 \mathrm{ml}$ of the cell suspension was further subcultured in $5 \mathrm{ml}$ of KB broth. After 24 or $48 \mathrm{hr}$ of shake culture at $28 \mathrm{C}$, the bacteria were diluted appropriately in distilled water, $0.2 \mathrm{ml}$ of the bacterial suspension was spread on solid $\mathrm{KB}$, and the plates were incubated at $28 \mathrm{C}$ for $48-72 \mathrm{hr}$. The colonies thus obtained were subcultured on $\mathrm{KB}$ slants or $\mathrm{KB}$ plates, and their Cor productivity was examined.

Table 1. Strains of Pseudomonas syringae pv. atropurpurea used in this experiment

\begin{tabular}{ccl}
\hline \multicolumn{1}{c}{ Strains } & Phenotype ${ }^{\mathrm{a}}$ & \multicolumn{1}{c}{ Origin } \\
\hline NIAS $1304^{\mathrm{b}}$ & WT Cor $^{+}$ & Diseased Italian ryegrass \\
NIAS 1308 & WT Cor & ditto \\
NIAS 1309 & WT Cor & ditto \\
NIAS 1313 & Cor & Spontaneous mutant of NIAS 1309
\end{tabular}

a) WT: Wild type, $\mathrm{Cor}^{+}$: Positive in coronatine productivity, $\mathrm{Cor}^{-}$: Negative in coronatine productivity

b) List of cultures in the Plant Pathology Division of National Institute of Agricultural Sciences (Misc. Publ. Natl. Inst. Agric. Sci., Ser. C, No. 3, by Nishiyama et al.) 
Bioassay of coronatine production. Cor production of the bacterium was assayed by the method described previously $y^{10)}$. Young bacterial culture was inoculated to the small pieces (about $2 \times 2 \times 0.6 \mathrm{~cm}$ ) of potato tuber placed on the moistened filter paper in a Petri dish. Cor production was checked by the hypertrophic growth of inoculated tuber pieces after 5 days incubation at $23 \mathrm{C}$. The test was repeated 3 times when negative reaction was observed.

\section{Results}

Relationship between coronatine productivity and an indigenous plasmid in pseudomonas syringae pv. atropurpurea

Relation between pathogenicity-related properties, such as Cor productivity and multiplication ability in Italian ryegrass, and the presence of a specified plasmid in pv. atropurpurea was studied. The experiments for detecting indigenous plasmids in four strains of pv. atropurpurea (Table 1) were carried out by the agarose gel electrophoresis. A plasmid of approximately 58 Mdal molecular weight was detected from two strains

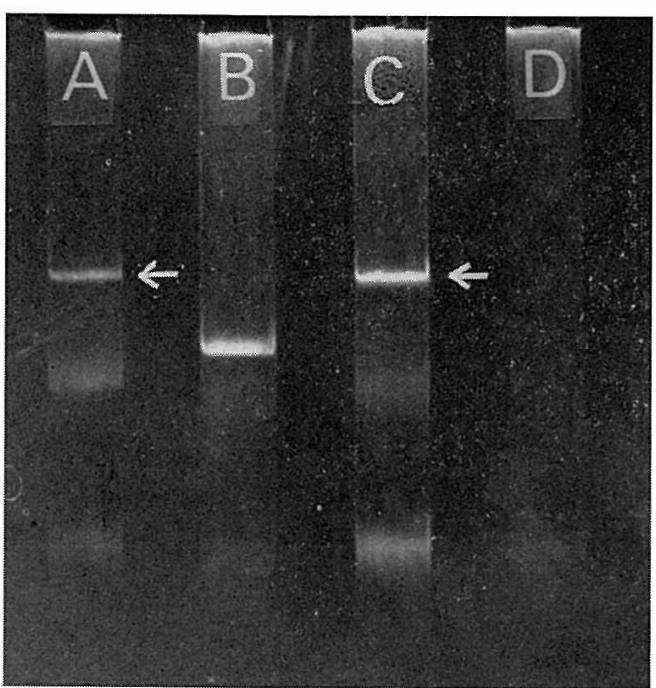

Fig. 1. Agarose gel electrophoresis of plasmid DNA isolated from Pseudomonas syringae pv. atropurpurea.

A ; NIAS $1304\left(\right.$ Cor $\left.^{+}\right)$, B ; NIAS $1308\left(\right.$ Cor $\left.^{-}\right)$ C ; NIAS $1309\left(\mathrm{Cor}^{+}\right)$, D ; NIAS $1313\left(\right.$ Cor $\left.^{-}\right)$ Arrows show pCOR1 plasmid.

(virulent and $\mathrm{Cor}^{+}$), whereas both avirulent strains ( $\mathrm{Cor}^{-}$) of NIAS 1313 (a spontaneous mutant from NIAS 1309) and NIAS 1308 (an isolate from the diseased plant) did not show the $58 \mathrm{Mdal}$ plamid DNA (Table 2 and Fig. 1). These results suggest that a close relationship exists between the $58 \mathrm{Mdal}$ plasmid and Cor productivity of the bacterium. However, the plasmid did not show any relationship with the ability of mltiplication in the host plant. The plasmid was, therefore, named as pCORl here.

Further experiments were performed using 32 virulent strains and 37 avirulent strains of pv. atropurpurea isolated from halo blight lesions on the leaves of Italian ryegrass. As the results, plasmid DNA of about 58 Mdal corresponding to pCOR1 was detected from all virulent isolates of pv. atropurpurea tested, whereas it was

Table 2. Relationship between the properties related pathogenicity on Italian ryegrass and existance of pCORI plasmid in Pseudomonas syringae pv. atropurpurea

\begin{tabular}{ccccc}
\hline \hline Strains & Coronatine production & Multiplication ability & Pathogenicity & Existance of pCORl \\
\cline { 2 - 5 } NIAS 1304 & + & + & + & + \\
NIAS 1308 & - & + & + & - \\
NIAS 1309 & + & + & + & + \\
NIAS 1313 & - & + & - & - \\
\hline
\end{tabular}


Table 3. Detection of pCORl plasmid in the virulent and avirulent strains of Pseudomonas syringae pv. atropurpurea

\begin{tabular}{ccccc}
\hline $\begin{array}{c}\text { pv. atropur- } \\
\text { purea } \text { strain }\end{array}$ & $\begin{array}{l}\text { Coronatine } \\
\text { production }\end{array}$ & $\begin{array}{l}\text { No. of strains } \\
\text { tested (A) }\end{array}$ & $\begin{array}{l}\text { No. of pCOR1 } \\
\text { strains (B) }\end{array}$ & B/A(\%) \\
\hline Virulent strain & + & 32 & 32 & $32 / 32(100 \%)$ \\
Avirulent strain & - & 37 & 0 & $0 / 37(0 \%)$ \\
\hline
\end{tabular}

not detected in all avirulent strains (Table 3 ).

\section{Curing of coronatine productivity in Pseudomonas syringae pv. atropurpurea by acridine orange}

Young culture of pv. atropurpurea NIAS 1309 was treated with various concentrations of acridine orange ( $\mathrm{AO})$. Then, many colonies obtained were screened to search for Cor- mutants by the bioassay of coronatine production. As shown in Table 4 and Fig. 2, Cor $^{-}$mutants were obtained by the AO treatment at a concentration higher than $100 \mathrm{ppm}$. The frequency of the mutation was especially high $(10.7 \%)$ when the bacteria were treated at $200 \mathrm{ppm}$. The rough colony mutants were also obtained at a frequency ranging from 4.4 to $18.8 \%$ by the $\mathrm{AO}$ treatment.

Detection of pCORl from the 38 isolates of $\mathrm{Cor}^{-}$mutant was performed by the agarose gel electrophoresis. As shown in Table 5 and Fig. 3, the plasmid DNA of 58 Mdal was not found from any of the Cor- isolates. Twenty nine out of 38 isolates, however, still harboured a plasmid of approximately $40 \mathrm{Mdal}$, suggesting that DNA fragment of $18 \mathrm{Mdal}$ was deleted from pCORl (Fig. 2). On the contrary, all of the $182 \mathrm{Cor}^{+}$isolates including 8 rough colony type mutants treated with AO (75 to 200

Table 4. Curing of coronatine productivity in Pseudomonas syringae pv. atropurpurea NIAS 1309 by treatment with acridine orange (AO)

\begin{tabular}{|c|c|c|c|}
\hline \multirow{2}{*}{$\begin{array}{c}\text { Concentration of } \mathrm{AO} \\
(\mu \mathrm{g} / \mathrm{ml})\end{array}$} & \multicolumn{2}{|c|}{ No. of colonies } & \multirow{2}{*}{ Curing frequency $(\%)$} \\
\hline & Screened & Cor $^{-}$ & \\
\hline 75 & 31 & 0 & 0 \\
\hline 100 & 400 & 1 & 0.25 \\
\hline 150 & 336 & 1 & 0.30 \\
\hline 200 & 336 & 36 & 10.7 \\
\hline Total & 1103 & 38 & 3.4 \\
\hline
\end{tabular}

Table 5. Detection of pCOR1 plasmid in the coronatine producing wild types and non-producing mutants isolated from Pseudomonas syringae pv. atropurpurea NIAS 1309 treated with acridine orange

\begin{tabular}{cccc}
\hline \multirow{2}{*}{$\begin{array}{c}\text { Coronatine } \\
\text { production }\end{array}$} & \multicolumn{2}{c}{ No. of isolates } & $\begin{array}{l}\text { Frequency of } \mathrm{pCOR}^{+} \\
\text {isolates } \%\end{array}$ \\
\cline { 2 - 3 }+ & Screened & $\mathrm{pCOR1}^{+}\left(\mathrm{pCOR1- \textrm {d } ^ { \mathrm { a } } )}\right)$ & 0 \\
+ & 38 & $0(29)$ & 100 \\
\hline
\end{tabular}

a) The plasmid of about $40 \mathrm{Mdal}$ (probably a deficient pCORl).

b) Eight isolates of rough colony muțant were included. 


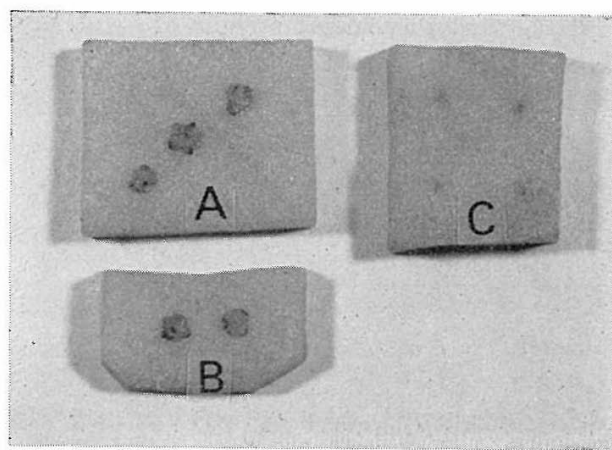

Fig. 2. Bioassay of coronatine production using the pieces of potato tuber. A, B; Wild type strain NIAS 1309 C; Cor- mutant of NIAS 1309 by treatment with acridine orange $(100$ ppm)

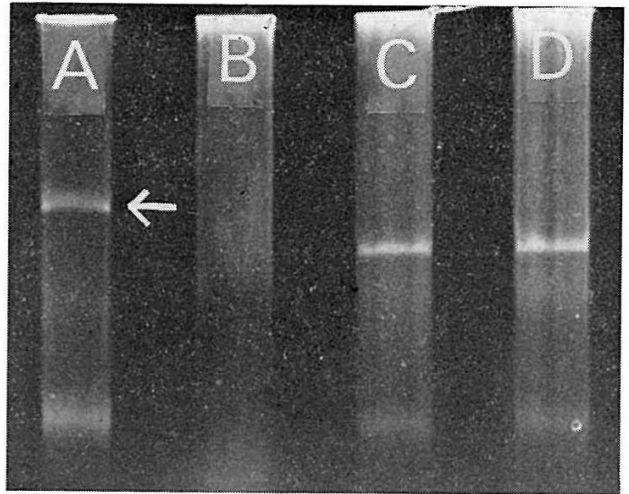

Fig. 3. Agarose gel electrophoretic analysis of plasmid DNA from wild type strain NIAS 1309 (A) and its Cormutants (B, $\mathrm{C}^{\mathrm{a})}, \mathrm{D}^{\mathrm{a})}$ ) obtained by treatment with acridine orage.

a) Molecular size of plasmid was approximately $40 \mathrm{Mdal}$. Arrows show pCOR1 plasmid.

ppm) still contained a whole pCOR1 plasmid. Slight change in colony morphology was observed in all of the cured Cor $^{-}$isolates after 2 to 3 days when they were subcultured.

\section{Discussion}

Cor productivity is an indispensable factor for the exhibition of halo blight lesions on the leaves by pv. atropurpurea ${ }^{7,10,11,14)}$. We concluded that Cor productivity was controlled by pCOR1 plasmid from the following reasons; 1) pCOR1 was always detected from all virulent $\left(\mathrm{Cor}^{+}\right)$strains of pv. atropurpurea, 2) the plasmid was not detectable from all Cor- mutants which lost Cor productivity spontaneously or by the treatment with $\mathrm{AO}, 3)$ it was also not detectable from avirulent strains of pv. atropurpurea isolated from Italian ryegrass.

A total of 29 isolates among $38 \mathrm{Cor}^{-}$mutants obtained by the AO treatment contained a plasmid of about $40 \mathrm{Mdal}$, which was suspected as a deficient pCOR1. Although it is suggested that $\mathrm{Cor}^{+}$gene (s) is encoded on the DNA fragment deleted from pCORl, further studies including restriction digestion analysis of pCORl or deleted DNA will be required in order to prove the hypothesis.

It has been reported that Cor is produced by various pathovars belonging to Pseudomonas syringae such as pv. glycine $a^{9}$, pv. maculicola ${ }^{10,11)}$, pv. morsprunorum ${ }^{10,11)}$. Some strains of these pathovars contain the same plasmid in molecular size as pCORl (Sato et al., unpublished data), suggesting that the Cor productivity in the pathovars other than pv. atropurpurea is also coded on the plasmid pCORl.

Avirulent strains which lost both of the Cor productivity and pCORl still maintain the ability of multiplication in the host plant. This fact suggests that genes concerning "multiplication" were not coded on pCORl but probably on chromosome.

In this study, a slight alteration of colony morphology was induced by curing pCORl. 
Similar phenomenon was observed in Pseudomonas syringae pv. phaseolicola when the indigenous plasmid of the bacterium was cured ${ }^{4)}$. Certain cell surface components ${ }^{5,6)}$ and periplasmic protein ${ }^{16)}$ have also been shown to be encoded by plasmid-borne genes in some phytopathogenic bacteria. Accordingly, besides Cor productivity, the synthesis of some kinds of protein related to colony morphology might also be encoded by pCOR1 in pv. atropurpurea.

We are grateful to Dr. S. Wakimoto, Professor of Kyushu University, Dr. T. Ishiie and Dr. K. Takahashi, Sericultural Experiment Station, for reading of the manuscript.

\section{Literature cited}

1. Birnboim, H. C. and Doly, J. (1979). Nucl. Acids Res. $7: 1513-1523$.

2. Comai, L. and Kosuge, T. (1980). J. Bacteriol. 143: 950-957.

3. Comai, L., Surico, G. and Kosuge, T. (1982). J. Gen. Microbiol. 128: 2157-2163.

4. Curiale, M. S. and Mills, D. (1982). J. Bacteriol. 152: 797-802.

5. Gonzalez, C. and Vidaver, A.K. (1978). Proc. Int. Conf. Pathogenic Bacteria 4:31-38.

6. Gonzalez, C. and Vidaver, A. K. (1980). Phytopathology $70: 223-225$.

7. Ichihara, A., Shiraishi, K., Sato, H., Sakamura, S., Nishiyama, K., Sakai, R., Furusaki, A. and Matsumoto, T. (1977). J. Am. Chem. Soc. 99: 636-637.

8. King, E. O., Ward, M. K. and Raney, D. E. (1954). J. Lab. Clin.Med. 44: 301-307.

9. Mitchell, R. E. (1982). Physiol. Plant Pathol. 20 : 83-89.

10. Nishiyama, K. (1981). Bull. Nat. Inst. Agr. Sci. Ser. C. 35: 1-55.

11. Nishiyama, K. and Ezuka, A. (1978). Ann. Phytopath. Soc. Japan 44: 179-183.

12. Nishiyama, K. and Ezuka, A. (1979). Ibid. 45: 556 (Abstr.).

13. Nishiyama, K. and Ezuka, A. (1977). Ibid. 43: 426-431.

14. Nishiyama, K., Sakai, R., Ezuka, A., Ichihara, A., Shiraishi, K. and Sakamura, S. (1977). Ibid. 43: 219-220.

15. Sato, M., Staskawicz, B. J., Panopoulos, N. J., Peters, S. and Honma, M. (1981). Plasmid 6: 325-331.

16. Sonoki, S. and Kado, C. I. (1978). Proc. Natl. Acad. Sci. U. S. A. $75: 3796-3800$.

17. Staskawicz, B. J., Sato, M. and Panopoulos, N. J. (1981). Phytopathology 71: 257 (Abstr.).

18. Tominaga, T. (1968). Ann. Phytopath. Soc. Japan 34:242-249.

19. Van Larebeke, N., Genetel-o, C., Schell, J., Schilperoort, R. A., Hermans, A. K., Hernalsttens, J. P. and Van Montagu, M. (1975). Nature 255: 742-743.

20. Watson, B., Currier, T., Gordon, M. P., Chilton, M. D. and Nester, E. M. (1975). J. Bacteriol. $123: 255-264$. 
和 文 摘 要

\title{
Pseudomonas syringae pv. atropurpurea のコロナチン
}

\author{
生産性とプラスミド DNA との関係
}

佐藤 守・西山幸司・白田 昭

ライグラス類かさ枯病細菌 Pseudomonas syringae pv. atropurpurea の病原性発現には，本菌のコロナチ ソ (Cor) 生産が不可欠である。このCor 生産性と特定のプラスミドとの関係を調べた。野生株 NIAS 1309 を含む34株の Cor 生産株 $\left(\mathrm{Cor}^{+}\right)$からプラスミドの検出を行った結果, すべての菌株から約 $58 \mathrm{Mdal}$ のプラ スミド（pCORl と命名）が検出された。一方 NIAS 1309 から得られた Cor- 変異株扣よび多数の野外分離 菌の Cor- 株からは, pCOR1 が検出されなかった。さらに, NIAS 1309 をアクリジン処理をし，得られた Cor- 変異株38株は，いずれる同時に pCOR1 を失っていたが，それらのうち29菌株は pCOR1 の一部の DNA が欠失したと思われる約 $40 \mathrm{Mdal}$ のプラスミドを所持していた。以上の結果から，本菌のコロナチン生産性 はプラスミド支配による可能性が極めて強いものと結論した。 